\title{
Prevalence and seasonal transmission of Schistosoma haematobium infection among school-aged children in Kaedi town, southern Mauritania
}

N'Guessan G C Gbalégba ${ }^{1,2^{*}}$, Kigbafori D Silué2,3, Ousmane Ba ${ }^{4}$, Hampâté Ba ${ }^{4}$, Nathan T Y Tian-Bi ${ }^{2,3}$, Grégoire $Y$ Yapi $^{5}$, Aboudramane Kaba ${ }^{2,3}$, Brama Koné2,6, Jürg Utzinger ${ }^{7,8}$ and Benjamin G Koudou ${ }^{1,2,9}$

\begin{abstract}
Background: Mauritania is at the fringe of transmission of human schistosomiasis, which mainly occurs in the southern and southeastern parts of the country. This study aimed to assess the influence of rainfall seasonality on the prevalence of Schistosoma haematobium infection among school-aged children in Kaedi, southern Mauritania.

Methods: Cross-sectional surveys (i.e. parasitological, malacological and observations on water-related human activities) were carried out in Kaedi between September 2014 and May 2015, during both the wet and dry seasons. A total of 2162 children aged 5-15 years provided a single urine sample that was subjected to S. haematobium diagnosis. Snails were sampled and checked for cercarial shedding. Water contact patterns of the local population were recorded by direct observation.

Results: The prevalence of S. haematobium was 4.0\% (86/2162, 95\% confidence interval (Cl): 3.2-4.9\%) with a geometric mean egg count per $10 \mathrm{ml}$ of urine of 3.7 (95\% Cl: 2.8-4.3). Being male (adjusted odds ratio (aOR) 1.78, 95\% Cl: 1.13-2.80), being at primary school (aOR 1.73, 95\% Cl: 1.04-2.87) and dry season (aOR 0.56, 95\% Cl: 0.35-0.89) were significantly associated with S. haematobium. Among 284 potential intermediate host snail specimens collected over the rainy and dry seasons, three species were identified: Bulinus senegalensis $(n=13)$ and B. forskalii $(n=161)$ in the rainy season, and $B$. truncatus $(n=157)$ in the wet season. No snail was shedding cercariae. On average, seven human water contacts were recorded per hour per observer over a 28-day observation period. Twelve types of water contact activities were identified among which, swimming/bathing was predominant $(n=3788,36.9 \%)$, followed by washing clothes $(n=2016,19.7 \%)$ and washing dishes $(n=1322,12.9 \%)$. Females $(n=5270,51.4 \%)$ were slightly more in contact with water than males $(n=4983,48.6 \%)$. The average time spent in the water per person per day was $14.2 \mathrm{~min}$ (95\% Cl: 13.8-14.6 min). The frequency and duration of water contact followed a seasonal pattern.

Conclusion: Our findings demonstrate a low prevalence and intensity of S. haematobium among school-aged children in Kaedi. Appropriate integrated control measures, including health education among at-risk communities and snail control may help to interrupt transmission of S. haematobium in Kaedi.
\end{abstract}

Keywords: Prevalence, Schistosoma haematobium, Seasonal transmission, Snails, Water contact, Urban area, Mauritania

\footnotetext{
*Correspondence: gbalegba@yahoo.fr

'Unité de Formation et de Recherche Sciences de la Nature, Université

Nangui Abrogoua, 02 B.P. 801, Abidjan 02, Côte d'Ivoire

${ }^{2}$ Centre Suisse de Recherches Scientifiques en Côte d'Ivoire, 01 B.P. 1303,

Abidjan 01, Côte d'Ivoire

Full list of author information is available at the end of the article
} 


\section{Background}

Schistosomiasis is one of the most widespread human parasitic diseases in terms of socioeconomic and public health impact in tropical and subtropical areas [1]. More than 250 million people are infected and the number of people needing preventive treatment in 2015 was estimated at 201 million [2, 3]. Approximately 85\% of infections occur in sub-Saharan Africa and at least $90 \%$ of people requiring treatment for schistosomiasis live in Africa [4].

Various factors are responsible for the persistent transmission of schistosomiasis in sub-Saharan Africa. These include living in close proximity to water bodies, such as irrigation schemes and dams, as well as socioeconomic factors such as occupational activities, poverty and climate change [5-8]. The Sahel region is characterized by long periods of drought, which makes it difficult for its inhabitants to reach agricultural self-sufficiency. However, in the 1970s and 1980s, various irrigation systems have been installed throughout the region to enhance agriculture and food production [9]. Thus, important development programmes have been implemented, including the construction of large dams on the Senegal River $[10,11]$ that strongly influences cities located on the right borders of the river.

The current schistosomiasis control strategy is mainly based on preventive chemotherapy that is the periodic administration of the antischistosomal drug praziquantel to school-aged children and other high risk groups [12, 13]. Praziquantel reduces morbidity and might impact on transmission, but rarely eliminates infection $[14,15]$. A major shortcoming to schistosomiasis control is the low coverage of preventive chemotherapy. In 2015, for example, only $26.8 \%$ of the people requiring preventive chemotherapy were administered praziquantel [3].

In Mauritania, transmission of schistosomiasis primarily occurs in the south and southeast where the prevalence might range from $1.3 \%$ to $90 \%$ [16, 17]. Shortly, after the construction of the Diama and Manantali dams, there was an outbreak of Schistosoma mansoni [18, 19]. Despite a mass distribution campaign of praziquantel in the country, transmission of schistosomiasis persists within the communities [17]. In Kaedi, most water contact activities of the local population occur in the Senegal River.

The current study was designed to deepen our understanding of the transmission of S. haematobium in Kaedi. Our findings are discussed in the frame of integrated schistosomiasis control and, indeed, current efforts that aim at elimination of schistosomiasis [20].

\section{Methods}

\section{Study area and population}

The study was carried out in Kaedi town, southern Mauritania. Kaedi is located approximately $430 \mathrm{~km}$ from the capital Nouakchott. Kaedi is the main town of the Gorgol region (Fig. 1). The climate is Sahelian, with a 4month-long rainy season (June-September) and a dry season for the rest of the year. The rainy season is characterized by short, at times violent rainfalls with a peak in August. During the dry season, there is a lack of precipitation with a somewhat cooler period from October to February and a hotter period from February to June. Minimum temperatures range from $12{ }^{\circ} \mathrm{C}$ in December to $30{ }^{\circ} \mathrm{C}$ in January, while maximum temperatures vary between $30{ }^{\circ} \mathrm{C}$ in January and $45{ }^{\circ} \mathrm{C}$ in June. The annual precipitation ranges from 300 to $500 \mathrm{~mm}$. Kaedi is located along the Senegal River, which represents the main water body. The main occupation of the inhabitants is subsistence farming of vegetables, millet and sorghum. Livestock farming is done by mobile pastoralists. The wet season is the period of intensive agricultural activities, specifically rice paddy cultivation in "Périmètre Pilote du Gorgol 1" (PPG1) and "Périmètre Pilote du Gorgol 2" (PPG2), which are the two main rice growing areas (Fig. 1). All children between the ages of 5 and 15 years from randomly selected households were eligible for participation in the study, and hence, were invited to provide a single urine sample for the diagnosis of S. haematobium.

\section{Study design, sample size determination and household selection}

Cross-sectional surveys (parasitological, malacological and observations of human water-related activities) were carried out simultaneously in September 2014, and in May 2015 during the wet season and dry season, respectively. The parasitological surveys were carried out in each season, using a community-based approach. Households were selected randomly from 11 districts of the city. The number of households per district was proportionally allocated according to the population size of each district (Fig. 2). The sample size (n) was adjusted to 728 households obtained by using the formula $n=\frac{\delta^{2} \times P(1-P) \times C}{i^{2}}$, where $\delta$ is the standard deviation (1.96), $P$ is the expected prevalence (35\%) based on Ouldabdallahi et al. [16], $i$ is the precision or margin of the error (5\%) and $C$ is the correction coefficient $(C=2)$.

\section{Urine collection and microscopic examination}

Participants were invited to provide a single urine sample in a $15 \mathrm{ml}$ empty sterile container. Urine samples were collected between 10:00 and 14:00 h directly at the households. Urine sample were subjected to the filtration method, as described elsewhere [21]. In brief, $10 \mathrm{ml}$ of vigorously shaken urine were gently pressed through a filter $(12-\mu \mathrm{m}$ polycarbonate filter). The filter was placed on a microscope slide and a drop of Lugol's 


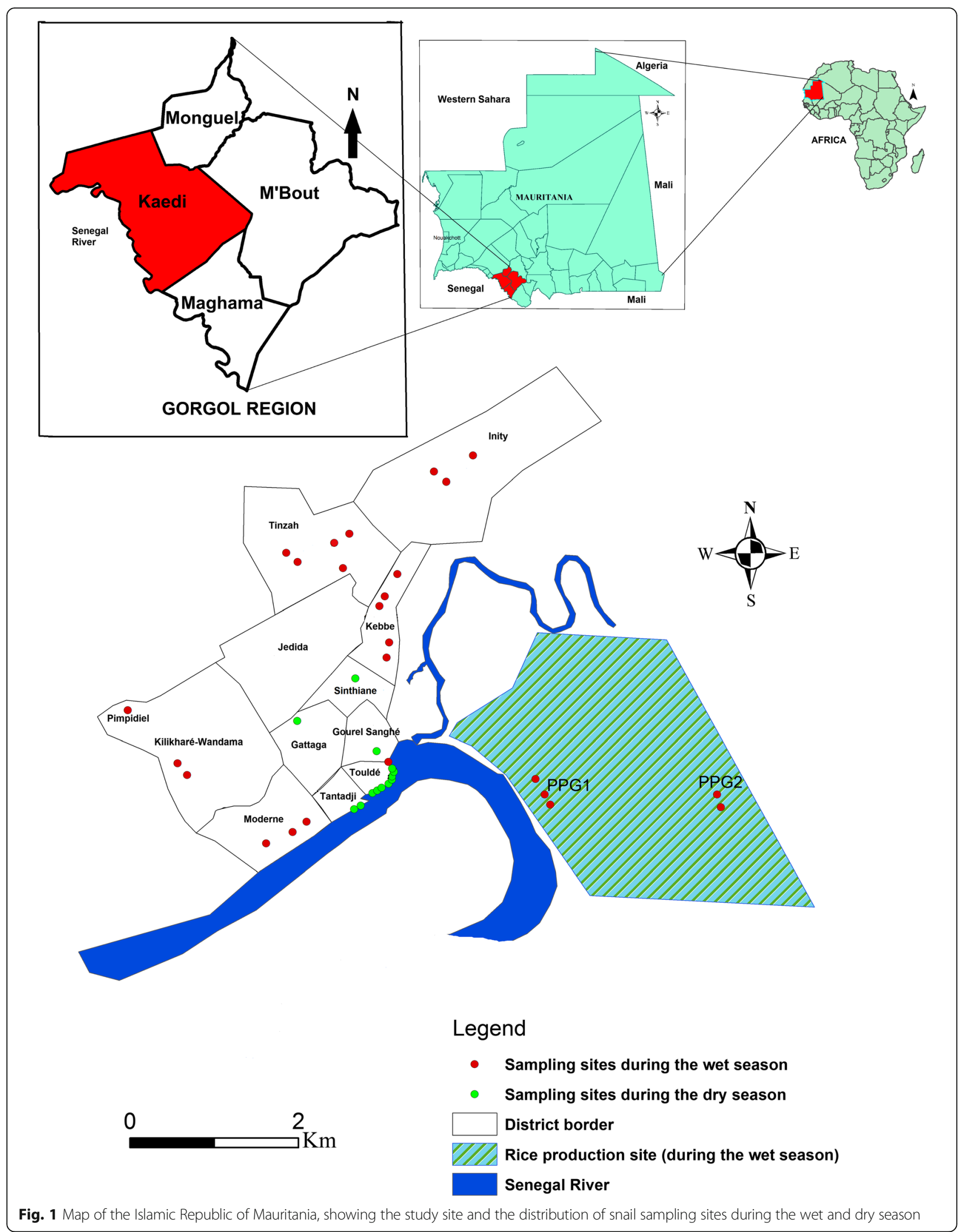




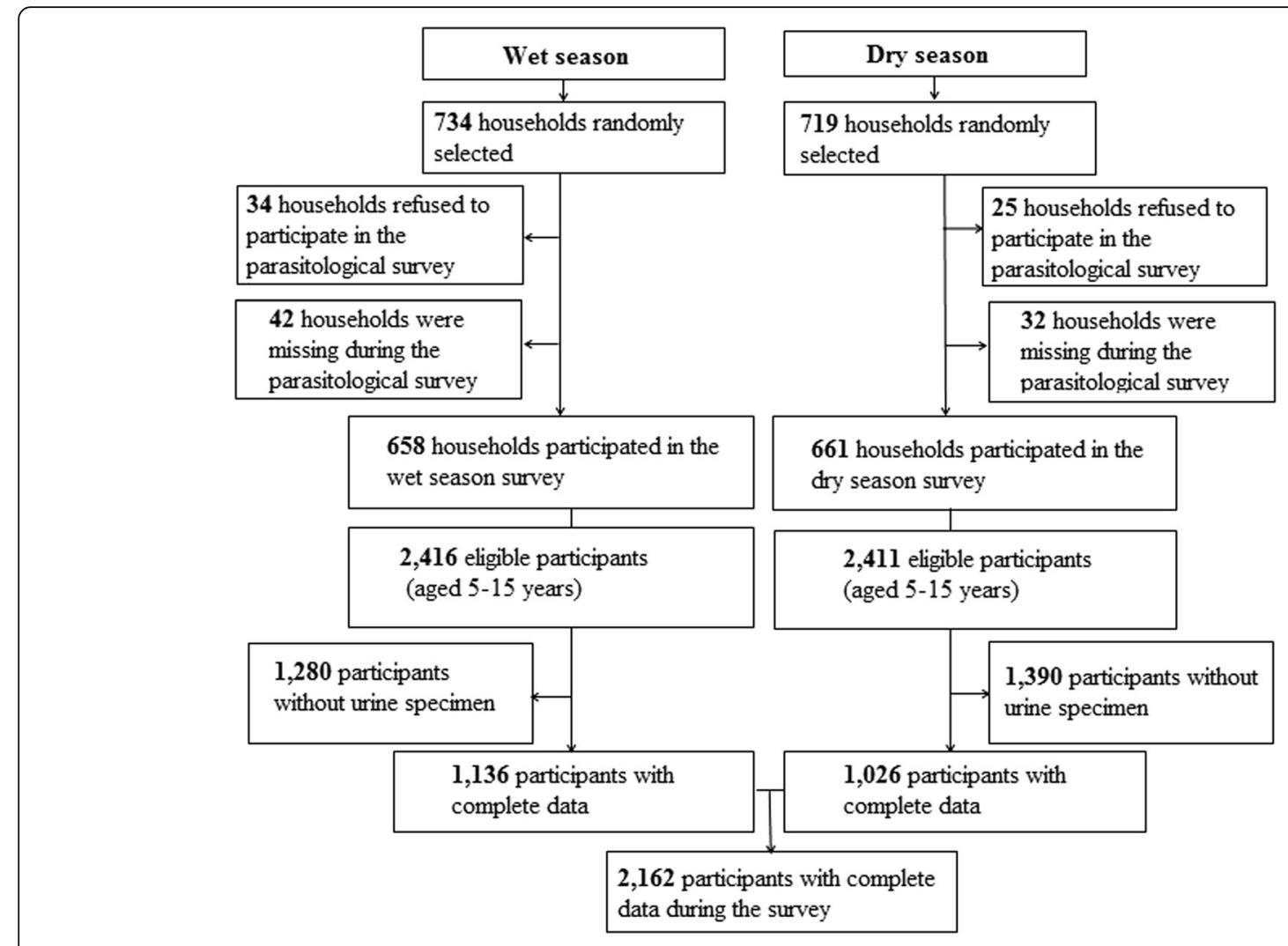

Fig. 2 Flow chart showing the study cohort and compliance on the study participants in Kaedi, southern Mauritania, 2014/2015

iodine solution was added before quantitative examination under the microscope by two experienced laboratory technicians at an X 100 magnification. Eggs were counted and recorded as number of eggs $/ 10 \mathrm{ml}$ of urine. Infection intensity was classified as light $(<50$ eggs/ $10 \mathrm{ml}$ of urine) or heavy ( $\geq 50$ eggs/10 $\mathrm{ml}$ of urine), according to guidelines put forth by the World Health Organization (WHO) [22]. For quality control, $10 \%$ of the slides were re-examined by a senior laboratory technician.

\section{Snail sampling}

A preliminary investigation in Kaedi was conducted to identify sites where people were involved in water contact activities. Owing to the Sahelian climate, ponds are scarce in Kaedi. This allowed us to identify and visit all available water-contact points $(n=39)$. Snails were collected during five consecutive days both in the dry and wet season at each water-contact site (Fig. 1) by two previously trained field enumerators using standard snail scoops or, occasionally, by hand collection. Sampling time was fixed at $15 \mathrm{~min}$ per collection site [23]. The geographical coordinates of the visited sites were determined using a global positioning system (GPS MAP 62, Garmin; Olathe, KS, USA). The snail density was expressed as the number of snails collected per collector during $15 \mathrm{~min}$ at each site [24]. Snails were transfered in small boxes designed for their transportation from the field to the laboratory. In the Kaedi Health Centre laboratory, snails were rinsed with tap water and identified to genus or species level, according to readily available identification keys $[25,26]$ and examined for schistosome infection by cercarial shedding. Each snail specimen identified as potential intermediate host of schistosomiasis was placed in a small plastic cup containing $20 \mathrm{ml}$ of distilled water and exposed to direct artificial light (36 W neon) for 20-35 min. Patent infections in snails were subsequently investigated using a binocular lens against a dark background. The ratio of the number of snails shedding Schistosoma spp. cercariae to the total number of snails tested represented the prevalence. During each season, all intermediate host snails were tested up to a full cycle of 30 days.

\section{Human water-contact activities}

Direct observations were made with an emphasis on the behaviour of community members in order to understand how they might become infected with schistosomes. These observations took place in close proximity to the river widely used by people in the city. Two sites were selected each season. Site 1 was a rice perimeter at PPG1, while site 2 was around Senegal River. During the dry season, PPG1 site was replaced by another site on 
the river bank (because there was no rice cultivation during this period), while site 2 was maintained. Behaviours of community members during water contact were recorded each day from 06:00 to 19:00 $\mathrm{h}$ during each season by trained observers [27]. A supervisor randomly visited the observers several times per day to make sure that they adhered to standard protocols [28]. Each individual who was in contact with surface water was identified by the observer who then recorded the sex, the type of water-contact activity, the part of the body in contact with the water and the start and end time the water was contacted. Additionally, the age was estimated by considering three age groups: (i) < 10 years; (ii) $10-15$ years; and (iii) $>15$ years.

\section{Statistical analysis}

Data were entered with EpiData (EpiData Association; Odense, Denmark) and analyzed using Stata version 14.1 (Stata Corporation; College Station, TX, USA) [29]. Prevalence of infection was estimated as a proportion and compared via Pearson $\chi^{2}$ test. Data summaries were made using descriptive statistics. The number of $S$. haematobium eggs counted were transformed to $\log _{10}(x+1)$ values to normalize the distribution of the residuals values for statistical analyses. One-way ANOVA or Student's $t$-test was used to check any statistical difference in mean egg counts for S. haematobium between seasons, sex and age-groups. Bivariate and multivariable logistic regression analyses were employed to determine the association between dependent and independent variables. Factors with $P$-value $<0.05$ as identified at bivariate level were considered for the final model. An odds ratio (OR) with 95\% confidence interval (CI) was used to measure the strength of association between S. haematobium infection status and co-variables. A $5 \%$ level of significance was applied to all statistical tests.

\section{Results}

\section{Characteristics of the study participants}

The demographic characteristics of study participants during both wet and dry season in Kaedi town are summarized in Table 1. For the parasitological survey, a total of 4827 individuals aged 5-15 years were recruited. However, only $44.7 \%(n=2162)$ of the children provided urine samples. The sex ratio (male:female) was 0.97 with 1064 (49.2\%) being male. The mean age of the study participants was 9.3 years. The majority of recruited children who had complete data records (1335/2162; $61.7 \%$ ) attended primary school.

Prevalence, geometric means of egg counts and factors associated with S. haematobium

The prevalence and the geometric mean of egg counts (GMEC) of S. haematobium according to season and demographic characteristics are presented in Table 2. Of
Table 1 Characteristics of study participants in Kaedi, southern Mauritania, 2014/2015

\begin{tabular}{|c|c|c|c|}
\hline Variable & Frequency & $\%$ & $P$-value \\
\hline \multicolumn{4}{|l|}{ Sex } \\
\hline Male & 1064 & 49.2 & \multirow[t]{3}{*}{0.373} \\
\hline Female & 1098 & 50.8 & \\
\hline Sex ratio (males:females) & 0.97 & & \\
\hline \multicolumn{4}{|l|}{ Age group (in years) } \\
\hline $5-7$ & 761 & 35.2 & \multirow[t]{3}{*}{$<0.001$} \\
\hline $8-11$ & 783 & 36.2 & \\
\hline $12-15$ & 618 & 28.6 & \\
\hline Mean age & 9.3 & & \\
\hline \multicolumn{4}{|l|}{ Education level } \\
\hline No education & 446 & 20.6 & \multirow[t]{4}{*}{$<0.001$} \\
\hline Koranic school & 256 & 11.8 & \\
\hline Primary school & 1335 & 61.7 & \\
\hline Secondary school & 125 & 5.8 & \\
\hline \multicolumn{4}{|c|}{ Relationship to the household head } \\
\hline Child & 1468 & 67.9 & \multirow[t]{3}{*}{0.282} \\
\hline Other relatives & 663 & 30.7 & \\
\hline Without relatives & 31 & 1.4 & \\
\hline \multicolumn{4}{|l|}{ Household head occupation } \\
\hline Officials $^{a}$ & 209 & 14.0 & \multirow[t]{3}{*}{0.502} \\
\hline Non-officials ${ }^{b}$ & 943 & 63.3 & \\
\hline Unemployed & 339 & 22.7 & \\
\hline \multicolumn{4}{|c|}{ Household head education level } \\
\hline No education & 449 & 30.1 & \multirow[t]{5}{*}{0.470} \\
\hline Koranic school & 515 & 34.5 & \\
\hline Primary school & 252 & 16.9 & \\
\hline Secondary school & 209 & 14.0 & \\
\hline Higher academic level & 67 & 4.5 & \\
\hline \multicolumn{4}{|l|}{ Habitation zone $e^{c}$} \\
\hline Zone 1 & 775 & 35.8 & \multirow[t]{3}{*}{0.634} \\
\hline Zone 2 & 767 & 35.5 & \\
\hline Zone 3 & 620 & 28.7 & \\
\hline \multicolumn{4}{|l|}{ Season } \\
\hline Wet & 1026 & 47.5 & \multirow[t]{2}{*}{0.002} \\
\hline Dry & 1136 & 52.5 & \\
\hline Total & 2162 & 100.0 & \\
\hline
\end{tabular}

ancluding teachers, medical staff and administration staff

${ }^{b}$ Including famers, traders and craftsmen

CHabitation in the study site was divided in zones according to the distance to the Senegal River: zone 1, <200 m; zone 2, 201-500 m; zone 3, > $500 \mathrm{~m}$

the 2162 urine samples examined, 86 were positive (4.0\%, 95\% CI: 3.2-4.9\%) for S. haematobium eggs. The prevalence was significantly higher in males $(54 / 1064$; $5.1 \%)$ than females $(32 / 1098 ; 2.9 \%)\left(\chi^{2}=6.60, P=0.010\right)$ (Fig. 3). There was no statistically significant difference 
Table 2 Prevalence, geometric mean of eggs counts and factors associated with frequency of Schistosoma haematobium in Kaedi, southern Mauritania, 2014/2015

\begin{tabular}{|c|c|c|c|c|c|c|}
\hline \multirow[t]{2}{*}{ Variable } & \multicolumn{3}{|c|}{ Frequency of S. haematobium } & \multirow{2}{*}{$\begin{array}{l}\text { Bivariate } \\
\text { cOR (95\% Cl) }\end{array}$} & \multirow{2}{*}{$\begin{array}{l}\text { Multivariate } \\
\text { aOR }(95 \% \mathrm{Cl})\end{array}$} & \multirow[t]{2}{*}{ GMEC $(95 \% \mathrm{Cl})$} \\
\hline & $\bar{N}$ & Positive & Prevalence $(95 \% \mathrm{Cl})$ & & & \\
\hline$\overline{\text { Overall }}$ & 2162 & 86 & $4.0(3.2-4.9)$ & & & $3.67(2.80-4.31)$ \\
\hline \multicolumn{7}{|l|}{ Sex } \\
\hline Female & 1064 & 54 & $5.1(3.9-6.6)$ & 1.00 & 1.00 & $3.50(2.64-4.85)$ \\
\hline Male & 1098 & 32 & $2.9(2.1-4.1)$ & $1.78(1.14-2.78)$ & $1.75(1.11-2.77)$ & $3.38(2.58-4.76)$ \\
\hline$P$-value & & & 0.010 & & & $0.114^{b}$ \\
\hline \multicolumn{7}{|l|}{ Age group (in years) } \\
\hline $5-7$ & 761 & 35 & $4.7(3.4-6.5)$ & 1.00 & & $3.82(2.64-5.87)$ \\
\hline $8-11$ & 783 & 26 & $3.2(2.2-4.7)$ & $1.40(0.84-2.35)$ & & $3.74(2.70-5.58)$ \\
\hline $12-15$ & 618 & 25 & $4.0(2.7-5.9)$ & $1.14(0.68-1.93)$ & & $2.80(2.00-4.18)$ \\
\hline$P$-value & & & 0.436 & & & $0.522^{\mathrm{a}}$ \\
\hline \multicolumn{7}{|l|}{ Education level } \\
\hline No education & 446 & 25 & $5.6(3.8-8.2)$ & 1.00 & 1.00 & $4.17(2.74-6.95)$ \\
\hline Koranic school & 256 & 11 & $4.3(2.4-7.6)$ & $1.32(0.64-2.73)$ & $1.82(0.86-3.85)$ & $8.93(3.56-30.87)$ \\
\hline Primary school & 1335 & 45 & $3.4(2.5-4.5)$ & $1.70(1.03-2.81)$ & $1.79(1.07-2.99)$ & $2.91(2.34-3.70)$ \\
\hline Secondary school & 125 & 5 & $4.0(1.7-9.3)$ & $1.42(0.53-3.80)$ & $1.56(0.57-4.25)$ & $2.13(1.00-2.96)$ \\
\hline$P$-value & & & 0.217 & & & $0.013^{\mathrm{a}}$ \\
\hline \multicolumn{7}{|c|}{ Relationship with household head } \\
\hline Child & 1468 & 59 & $4.0(3.1-5.2)$ & 1.00 & & $3.32(2.63-4.26)$ \\
\hline Other relatives & 663 & 27 & $4.1(2.8-5.9)$ & $0.98(0.62-1.57)$ & & $4.17(2.69-7.17)$ \\
\hline Without relatives & 31 & 0 & - & - & & - \\
\hline$P$-value & & & 0.520 & & & $0.329^{b}$ \\
\hline \multicolumn{7}{|c|}{ Household head's education level } \\
\hline No education & 449 & 31 & $6.9(4.7-9.7)$ & 1.00 & & $4.17(3.09-6.17)$ \\
\hline Koranic school & 515 & 23 & $4.5(2.9-6.6)$ & $0.58(0.91-2.76)$ & & $5.10(3.89-7.38)$ \\
\hline Primary school & 252 & 21 & $8.3(5.2-12.4)$ & $0.81(0.46-1.45)$ & & $3.70(2.91-5.26)$ \\
\hline Secondary school & 209 & 9 & $4.3(2.0-8.0)$ & $1.65(0.77-3.53)$ & & $3.03(2.00-6.95)$ \\
\hline Higher academic level & 67 & 2 & $3.0(0.4-10.4)$ & $2.41(0.56-10.31)$ & & $7.38(3.78-19.49)$ \\
\hline$P$-value & & & 0.111 & & & $0.334^{\mathrm{a}}$ \\
\hline \multicolumn{7}{|c|}{ Household head's occupation } \\
\hline Non-officials ${ }^{c}$ & 943 & 61 & $6.5(5.0-8.2)$ & $0.48(0.25-0.93)$ & $0.49(0.25-0.95)$ & $3.39(2.70-5.41)$ \\
\hline Officials $^{d}$ & 209 & 14 & $6.7(3.7-11.0)$ & $0.46(0.21-1.05)$ & $0.46(0.20-1.03)$ & $2.97(2.70-7.38)$ \\
\hline Unemployed & 339 & 11 & $3.2(1.6-5.7)$ & 1.00 & 1.00 & $3.38(2.13-7.84)$ \\
\hline$P$-value & & & 0.076 & & & $0.476^{\mathrm{a}}$ \\
\hline \multicolumn{7}{|l|}{ Habitation zone } \\
\hline Zone 1 & 775 & 39 & $5.0(3.7-6.8)$ & $0.60(0.34-1.04)$ & & $4.42(3.32-6.75)$ \\
\hline Zone 2 & 767 & 28 & $3.6(2.5-5.2)$ & $0.83(0.46-1.51)$ & & $2.53(1.87-3.63)$ \\
\hline Zone 3 & 620 & 19 & $3.0(2.0-4.8)$ & 1.00 & & $3.70(2.48-6.05)$ \\
\hline$P$-value & & & 0.148 & & & $0.048^{\mathrm{a}}$ \\
\hline \multicolumn{7}{|l|}{ Season } \\
\hline Wet & 1026 & 29 & $2.8(2.0-4.0)$ & 1.00 & 1.00 & $4.80(3.01-8.48)$ \\
\hline Dry & 1136 & 57 & $5.0(3.9-6.5)$ & $0.55(0.35-0.87)$ & $1.71(1.07-2.74)$ & $5.10(3.25-8.84)$ \\
\hline$P$-value & & & 0.009 & & & $0.081^{b}$ \\
\hline
\end{tabular}

Factors with $P$-value $<0.05$ were identified at bivariate level and were considered for the multivariate model

${ }^{a}$ Obtained by ANOVA

${ }^{b}$ Obtained by Student's $t$-test

'Famers, traders, craftsmen

dTeachers, medical staff, administrators

Abbreviations: $a O R$ adjusted odds ratio, $\mathrm{Cl}$ confidence interval, cOR crude odds ratio, GEMC geometric mean of egg count, $\mathrm{N}$ number examined 


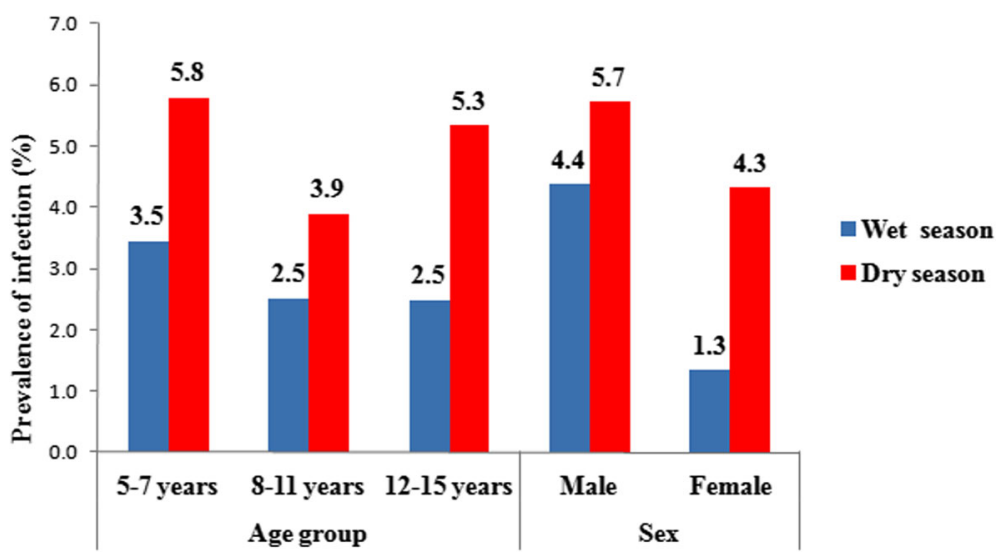

Fig. 3 Prevalence rate of S. haematobium infection, stratified by sex, age group and season in Kaedi, southern Mauritania, 2014/ 2015

between infection rates recorded within different age groups $\left(\chi^{2}=2.38, P=0.304\right)$, according to the education attainment of the parents/guardians $\left(\chi^{2}=7.50\right.$, $P=0.111$ ), the relationship with the head of households $\left(\chi^{2}=1.30, P=0.520\right)$, occupation of household heads $\left(\chi^{2}=5.15, P=0.076\right)$ and habitation zone $\left(\chi^{2}=3.82\right.$, $P=0.148)$. The prevalence of $S$. haematobium infection was significantly higher during the dry season $(57 / 1136$, $5.0 \%)$ compared to the rainy season $(29 / 1026,2.8 \%)$, $\left(\chi^{2}=6.76, P=0.009\right)$. The overall GMEC was 3.7 eggs/ $10 \mathrm{ml}$ of urine. In relation to sex, males ( 3.5 eggs/10 ml of urine) and females (3.4 eggs/10 ml of urine), had similar GMEC $(t=1.60, P=0.934)$. The intensity of infection varied significantly according to education level $\left(F_{(3,82)}=3.78, \quad P=0.013\right)$ and habitation zone $\left(F_{(2,83)}=3.15, P=0.048\right)$ but did not follow a seasonal variation $(t=1.76, P=0.081)$. Indeed, children from Koranic schools had the highest GMEC (8.9 eggs/10 $\mathrm{ml}$ of urine, 95\% CI: 3.6-30.9), while the lowest GMEC was recorded among children from secondary school (2.1 eggs/ $10 \mathrm{ml}$ of urine, 95\% CI: 1.0-2.9). The GMEC decreased according to age with 3.8 (95\% CI: 2.6-5.9), 3.7 (95\% CI: 2.7-5.6) and 2.8 (95\% CI: $2.0-4.2$ ) eggs/10 $\mathrm{ml}$ of urine in $5-7,8-11$ and $12-15$ years age groups, respectively.

The results of bivariate and multivariable analysis for the factors associated with S. haematobium infection are presented in Table 2 . In the bivariate analysis, male (crude OR, (cOR) 1.78, 95\% CI: 1.14-2.78), attending primary school (cOR 1.70, 95\% CI: 1.03-2.81), no officials (e.g. farmers, traders and craftsmen) as household head's occupation (cOR 0.48, 95\% CI: 0.25-0.93) and dry season (cOR 0.55, 95\% CI: 0.35-0.87) were significantly associated with $S$. haematobium. However, in the multivariable logistic regression analysis, only sex, educational attainment and season were significantly associated with $S$. haematobium. Males were nearly two times more likely to be infected with $S$. haematobium than females (adjusted OR, (aOR) 1.75, 95\% CI: 1.11-2.77). Children at primary school were nearly two times more likely to be infected than those who did not go to school (aOR 1.79, 95\% CI: 1.07-2.99). The dry season (aOR 1.71, 95\% CI: 1.07-2.74) appeared to be a high risk period of $S$. haematobium infection compared to the rainy season.

\section{Seasonal variation of snail abundance and infectivity}

A total of 39 sites in four habitats (i.e. rice fields, river bank, drain and temporary ponds) were surveyed, during the wet season $(n=26,66.6 \%)$ and during the dry season $(n=13,33.4 \%)$. During the dry season, 11 of the 13 sites were located on the Senegal River bank, whilst, in the wet season, only two of the 26 sites were located at this same place. Overall, 331 snails were collected during both seasons, 174 (52.6\%) and 157 (47.4\%) during the wet and dry seasons, respectively. Based on shell morphology, using readily available field identification keys, 13 (3.9\%), 157 (47.4\%) and 161 (48.6\%) of the snails were identified as Bulinus senegalensis, B. truncatus and $B$. forskalii, respectively. These three species have been identified as intermediate host snails of schistosomiasis. The snail abundance varied according to each species from dry to rainy season $(P<0.05)$. At the ecological level, snails were found in all habitats except in rice fields. Bulinus senegalensis (collected in drains) and B. forskalii (collected in temporary ponds) were collected only during the wet season, whilst $B$. truncatus were collected (only on the river bank) exclusively during the dry season. On the river bank, snails were abundant in areas under less human activities and with little vegetation. Most of the collected snails ( $n=298,90.0 \%)$ were tied to submerged plastic bags. Out of 284 snails subjected to shedding, no S. haematobium cercariae were found (Table 3).

\section{Water-related activities and duration}

A total of 10,253 human-water contacts during 28 observation days, corresponding to $145,710 \mathrm{~min}$, were 
Table 3 Seasonal inventory of the malacological fauna in Kaedi, southern Mauritania, 2014/2015

\begin{tabular}{|c|c|c|c|c|c|c|c|}
\hline \multirow[t]{2}{*}{ Biotope } & \multirow[t]{2}{*}{ Species } & \multicolumn{3}{|c|}{ Wet season } & \multicolumn{3}{|c|}{ Dry season } \\
\hline & & $\overline{n(\%)}$ & $n$ tested & $\overline{\mathbb{I R}}$ & $\overline{n(\%)}$ & $n$ tested & $\mathbb{R}$ \\
\hline Irrigation canal & B. senegalensis & $13(7.5)$ & 13 & 0 & $0(0)$ & 0 & - \\
\hline River bank & B. truncatus & $0(0)$ & 0 & - & $157(100)$ & 154 & 0 \\
\hline Temporary pond & B. forskalii & $161(92.5)$ & 117 & 0 & $0(0)$ & 0 & - \\
\hline Total & & $174(100)$ & 130 & 0 & $157(100)$ & 154 & 0 \\
\hline
\end{tabular}

Abbreviations: IR infection rate; $\mathrm{n}$, number of snails collected; $\mathrm{n}$ tested, number of snails tested

recorded (Table 4). The frequency of water-contact activities was higher during the wet season $(n=5707$, $55.6 \%)$ compared to the dry season $(n=4546,44.4 \%)$ $(P<0.001)$. Twelve water-contact activities were recorded during the study. These activities were categorized in five types: (i) professional (e.g. fishing), (ii) domestic, (iii) recreational, (iv) ritual and (v) other diverse activities. Regarding categories of activities, recreational activities $(n=3909,38.1 \%)$ were the main activities, followed by domestic activities $(n=3697$, $37.4 \%)$, other activities include animal washing/watering, washing motorized machines $(n=1888,18.4 \%)$, professional $(n=533,5.2 \%)$ and ritual $(n=226,2.2 \%)$ activities. During the dry season, rice cultivation frequency was zero, because the paddy cultivation took place only during the wet season in PPG1 and PPG2 sites. The majority of professional activities $(n=453,85 \%)$ took place during the wet season. Concerning the recreational activities, the frequency recorded was three times higher during the wet season $(n=3091,81.6 \%)$ compared to the dry season ( $n=697,18.40 \%),\left(\chi^{2}=6.11, P=0.013\right)$. Regarding sex, females $(n=5270,51.4 \%)$ were more in contact with water than their male counterparts $(n=4983,48.6 \%)(P<0.001)$ and spent more time (average duration $15.9 \mathrm{~min}$ (95\% CI: 15.2-16.7 $\mathrm{min}$ ) in water than males (average duration $14.2 \mathrm{~min}$ (95\% CI: 13.1-15.3 min) (Fig. 4). Female contacts with water were mainly related to domestic activities (55.7\% of contacts), followed by recreational activities (37.8\% of the contacts). In contrast, males were firstly attracted by water for recreational activities (38.8\% of contacts), such as swimming, followed by other various activities such as washing/watering livestock and washing

Table 4 Overview of frequency, duration and average duration of water contact in Kaedi, southern Mauritania, 2014/2015

\begin{tabular}{|c|c|c|c|c|c|c|}
\hline \multirow[t]{2}{*}{ Activities } & \multicolumn{3}{|l|}{ Wet season } & \multicolumn{3}{|l|}{ Dry season } \\
\hline & Frequency & $\begin{array}{l}\text { Total duration } \\
\text { (min) }\end{array}$ & $\begin{array}{l}\text { Average duration (min) } \\
(95 \% \mathrm{Cl})\end{array}$ & Frequency & $\begin{array}{l}\text { Total duration } \\
\text { (min) }\end{array}$ & $\begin{array}{l}\text { Average duration (min) } \\
(95 \% \mathrm{Cl})\end{array}$ \\
\hline \multicolumn{7}{|l|}{ Professional } \\
\hline Fishing & 178 & 13,519 & $75.9(67.4-84.5)$ & 156 & 2080 & $13.4(11.5-15.1)$ \\
\hline Rice farming & 301 & 3423 & $11.4(10.5-12.2)$ & - & - & - \\
\hline Gardening & 41 & 1045 & $25.5(19.0-31.9)$ & 52 & 286 & $5.5(4.9-6.1)$ \\
\hline \multicolumn{7}{|l|}{ Domestic } \\
\hline Fetching water & 223 & 971 & $4.4(3.7-5.0)$ & 136 & 665 & $4.9(4.2-5.5)$ \\
\hline Washing clothes & 581 & 21,792 & $37.5(34.9-40.1)$ & 1435 & 14,016 & $9.8(9.5-10.0)$ \\
\hline Washing dishes & 660 & 12,221 & $18.5(17.4-19.6)$ & 662 & 7112 & $10.7(10.2-11.3)$ \\
\hline \multicolumn{7}{|l|}{ Recreative } \\
\hline Swimming (bathing) & 3091 & 47,336 & $15.3(14.8-15.8)$ & 697 & 5852 & $8.4(8.0-8.8)$ \\
\hline \multicolumn{7}{|l|}{ Ritual } \\
\hline Ablution / worship of water & 216 & 1026 & $4.8(0.8-8.7)$ & 10 & 56 & $5.6(4.0-7.2)$ \\
\hline Micturate / drinking & 27 & 38 & $1.4(1.1-1.7)$ & 160 & 316 & $2.0(1.6-2.3)$ \\
\hline \multicolumn{7}{|l|}{ Other activities } \\
\hline Animals washing or watering & 223 & 4130 & $18.6(14.1-23.1)$ & 314 & 2542 & $8.1(7.5-8.7)$ \\
\hline Walking & 108 & 336 & $3.1(2.4-3.8)$ & 238 & 538 & $2.3(2.0-2.5)$ \\
\hline Washing motorized machine & 58 & 1254 & $21.6(17.0-26.2)$ & 182 & 2499 & $13.7(12.7-14.8)$ \\
\hline (Dis) embarking & - & - & - & 504 & 2658 & $5.3(5.1-5.4)$ \\
\hline Total & 5707 & 107,091 & $18.8(18.2-19.4)$ & 4546 & 38,619 & \\
\hline
\end{tabular}




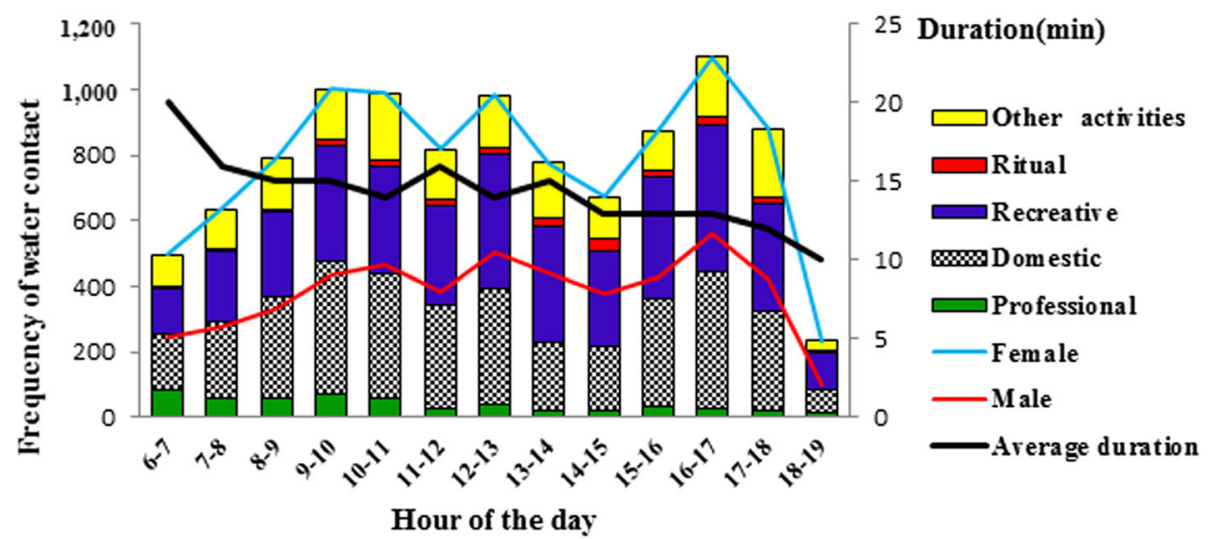

Fig. 4 Frequency of water contact by hour, category of activity, sex and mean duration of contact in Kaedi, southern Mauritania, 2014/2015

motorized machines (31.6\% of contacts). However, according to age, adolescents and adults ( $>15$ years, $n=4385$, $42.8 \%)$ were most in contact with water, followed by those aged $10-15$ years $(n=3653,35.6 \%)$ and those $<10$ years old ( $n=2215,21.6 \%)$. The average time spent in the water per person per day was $14.2 \mathrm{~min}$ (95\% CI: 13.8-14.6 min). This mean was higher during the wet season (18.8 min; 95\% CI: 18.2-19.4 min) compared to the dry season (8.5 $\mathrm{min}, 95 \% \mathrm{CI}: 8.3-8.7 \mathrm{~min}$ ). The intensity of contacts with water varied according to sex and the period of the day. Most intense water contacts occurred for males and females during three distinct peaks; first in the morning between 9:00 and 10:00 h, then around noon (12:00-14:00 h) and in the late afternoon (16:00-17:00 h) (Fig. 4).

\section{Discussion}

The present study extends our understanding of the seasonal transmission of $S$. haematobium in the urban area of Kaedi, southern Mauritania. As the Senegal River is the only source of permanent water supply for the Kaedi community, it is exceedingly difficult to prevent the community from contacting this essential source of water on a daily basis for various uses (bathing, swimming, fishing and other domestic uses). This water constitutes the main transmission foci of schistosomiasis in Kaedi.

The prevalence of $S$. haematobium infection among school-aged children was found to be $4.0 \%$, which classifies Kaedi town as a low endemic area [22]. This observed prevalence is low compared to previous studies with most studies conducted in different parts of southern Mauritania, known to be the main endemic area for schistosomiasis $[16,17,30]$. Our observed prevalence is considerably lower than that reported from other studies conducted in different parts of the Sahel, such as Burkina Faso (8.8\%) [31], Mali (7.6\%) [32] and Sudan (8.6\%) [33]. Various ecological features might explain these differences, as they influence the transmission of schistosomiasis [34]. The low prevalence of $S$. haematobium in the present study might also be attributable to the preventive chemotherapy campaigns conducted recently in the southern part of the country, including the Gorgol region by the national schistosomiasis control programme [17]. In the current study, males were nearly two times more likely to be infected with $S$. haematobium than females, though females were more often in contact with water than males. This is explained by genderspecific water-contact activities. The risk of infection among girls was lower than boys. Indeed, during swimming (the predominant water contact by boys), boys exposed their whole bodies in the water, while girls usually only exposed their legs and hands into the water, mainly in relation to carrying out domestic activities (e.g. fetching water, washing clothes and dishes, etc.) Moreover, during the wet season, people, particularly boys, work in rice paddies. The higher prevalence in boys compared to girls confirms other reports for S. haematobium infection in Mauritania [16, 17], Senegal [35], Benin [36] and Ethiopia [37]. However, this result is in contradiction with similar studies carried out in Uganda [38] and Nigeria [39], where females showed higher infection rates than males.

The age-related prevalence showed that all age groups were at similar risk to be infected. However, children aged 5-7 years were slightly more affected, probably because they are frequently involved in water-contact activities (e.g. swimming, washing or watering animals) and were perhaps not yet targeted by preventive chemotherapy.

Children at primary school were nearly two times more likely to be infected than those from the same age who did not go to school. How can this unexpected finding be explained? In Kaedi, parents who wish their children to attend the French-language training programmes, send their children to schools in Senegalese villages at the other side of the Senegal River. Crossing the river takes about $2 \mathrm{~min}$ in a motorized canoe. Every school day, around 13:00 h, when children return from school in neighbouring Senegal and get out of the canoe, 
they take a recreational swim before going home. We hypothesis that this specific behaviour is the main risk factor for acquiring S. haematobium infection.

The average intensity of S. haematobium infection (3.7 eggs $/ 10 \mathrm{ml}$ ) recorded was low. Indeed, it is less than that obtained in rural area of southern Mauritania [16]. Our finding showed that GMEC decreased with age. Similar observations have been reported by Dalton \& Pole [40], who observed lower GMEC among elderly people in a village situated in close proximity to a man-made lake in Ghana. This could be due to the development of partial immunity as reported elsewhere $[41,42]$.

A deeper understanding of snail ecology and the ecological mechanisms affecting transmission can play an important role in integrated control of schistosomiasis and other snail-borne diseases [43]. Three species of snails that are known as intermediate hosts for $S$. haematobium (i.e. B. truncatus, B. senegalensis and B. forskalii) were collected from the study area. Bulinus truncatus and B. forskalii species were reported recently for the first time on the Mauritanian side of the Senegal River, while $B$. forskalii has not previously been identified as an intermediate host of $S$. haematobium in Mauritania [16]. The high occurrence of B. truncatus found during the dry season, coupled with the high prevalence of infection during this season suggests that active transmission of S. haematobium occurs in Kaedi during the dry season. During the dry season, water movements are expected to be low, thus offering a stable environment for snails to proliferate without being washed away [44]. Bulinus truncatus was reported in other studies carried out in the Senegal River basin in Mauritania [16]. Bulinus senegalensis were collected only during the wet season in an irrigated canal because in Kaedi, paddies rice cultivation is only pursued in the wet season. Previous studies reported that $B$. senegalensis could survive for 6-8 months when ponds are dry [45]. Bulinus senegalensis was reported for the first time on the Mauritanian side of the Senegal River during 20052006 and laboratory experiments indicated its role as an intermediate host for S. haematobium in Mauritania [16]. Bulinus senegalensis was already involved in S. haematobium transmission in the Senegal River basin [46, 47]. This species is endemic in West Africa, mainly in Sahelian area and was recorded in the Union for Conservation of Nature (IUCN) Red List of threatened species in 2010 [48]. At the ecological level, the present study revealed that, intermediate host snails of S. haematobium could breed in both natural (river bank) and man-made habitats (drains). However, out of the 284 snails tested, none was found to be shedding cercariae. The absence of infected snails could indicate that there is a low snail-S. haematobium compatibility, or the regular implementation of mass drug administration in the study area [17]. Based on the seasonal fluctuation of snails, focal mollusciciding at the beginning of the rainy season should be considered in an effort to eliminate the disease [20].

Water-contact studies are useful for determining major human activities that create a high risk of exposure to schistosome infection in areas where it occurs [49]. There is much scientific evidence that sociodemographic variables and contact with unsafe water are associated with schistosomiasis [50]. Our findings show that swimming/bathing was the main activity, followed by washing clothes and dishes. This result is in line with another study conducted in the Senegal River basin [28]. In sub-Saharan Africa, the most important water contact activity among children is swimming with a frequency depending on the variability of ambient temperature and humidity [50]. Laundry, bathing and recreational swimming are the activities that are causing the most exposure to cercaria-infested water, while the collection of water for drinking seems to pose a minor threat because it does not involve the immersion of large body parts, for long periods [51]. Changing the frequency and/or nature of water contact of communities living in Kaedi is not a feasible means of preventing schistosomiasis transmission. The same conclusion was drawn before for a Mauritanian village [52]. Limiting access to the river as a strategy to reduce transmission, during high-risk periods, as proposed in Sourou Valley of Burkina Faso [53] may not be feasible in Kaedi. Females had greater contact with water than males. This can be explained by the fact that females had simultaneously more than one water-contact activity compared to males. This result is in agreement with findings reported in villages of northern Senegal [54].

The average time spent in the water per person per day in the present study was $14.2 \mathrm{~min}$. Other studies also pursuing direct observations reported considerably shorter water contact activities; $5.5 \mathrm{~min}$ in a Mauritanian village [52], $2.4 \mathrm{~min}$ in Kenya [55] and $4.3 \mathrm{~min}$ in Senegal [28]. Though it is known that the peak of cercarial shedding is around noon $[50,56]$, a long duration of contact with water is considered the more important risk factor for exposure to $S$. haematobium than frequency of the water contact [39]. The number and duration of daily contacts with water plays an important role in determining the relative risk of infection.

Our study has several limitations that should be taken into consideration when interpreting the results. First, the current level of infection may be underestimated. Indeed, during the door-to-door sample collection, some urine samples were provided earlier in the morning (due to logistical reasons) because several participants (schoolchildren) went to school. Normally, urine samples are collected between 10:00 and 14:00 $\mathrm{h}$ when 
schistosome eggs are most abundant in urine. In addition, direct observations tend to under-report water contacts taking place outside the observation periods or outside the selected sites [56].

\section{Conclusion}

Urogenital schistosomiasis was found to be present at very low prevalence and intensity, with seasonal variation in Kaedi, southern Mauritania. Based on our findings, Kaedi is an area of low endemicity for S. haematobium. Preventive chemotherapy with praziquantel should be implemented in Kaedi during the dry season. In addition, management of the river bank by elimination of plastic bags, focal mollusciding, provision of safe water supply, sanitary facilities and implementation of continuous health education campaigns will be essential to eliminate S. haematobium. Agricultural activities performed during the wet season in the Gorgol throughout intensive rice paddy cultivation need to be also investigated to understand the contribution of anthropogenic factors in the transmission of S. haematobium.

\section{Abbreviations}

aOR: Adjusted odds ratio; Cl: Confidence interval; cOR: Crude odds ratio; GMEC: Geometric mean of egg count; GPS: Global positioning system; IDRC: International Development Research Centre; IUCN: International Union for Conservation of Nature; WHO: World Health Organization.

\section{Acknowledgements}

We thank the children, parents, the communities, health workers and the Regional Health Directorate of Kaedi. The authors are grateful to Mary Simwango and Sara Mwala for their contribution during the preparation of this manuscript. Particular thanks go to Dr. Mohamed O. Moukah, Dr. Jean T. Coulibaly and Dr. Jasmina Saric for their constructive comments and suggestions on earlier drafts of this manuscript. The authors also thank the other team members for their assistance during data collection.

\section{Funding}

This project received financial support from the UNICEF/UNDP/World Bank/ WHO Special Programme for Research and Training in Tropical Diseases (TDR) and the Canadian International Development Research Centre (IDRC), grant no. NB20283 (Dr. Brama Koné). The funders had no role in study design, data collection and analyses, decision to publish, or preparation of the manuscript.

\section{Availability of data and materials}

The datasets supporting the conclusions of this article are included within the article. Raw data used for analysis of the study are available from the corresponding author on reasonable request.

\section{Authors' contributions}

$B K, K D S, H B, O B, N T Y T B, G Y Y, B G K$ and JU designed the study; NGCG, HB, OB, AK, NTYTB and KDS executed the study. NGCG and AK analyzed the data. NGCG wrote the first draft of the manuscript. All authors read and approved the final draft of the manuscript before submission.

\section{Ethics approval and consent to participate}

The scientific committee of the Faculty of Medicine of the University of Nouakchott, acting as a national ethic committee, cleared the research protocol (reference no. 042/USTM/FM, dated 23 May 2013). In addition, local authorities in Kaedi were informed about the objectives, procedures, and potential risks and benefits of the study. Signed consent forms were obtained from parents or legal guardians for their children's participation. Participants aged between 12 and 17 years signed an assent form. All children included in the study were treated with albendazole (400 mg).
Those children found positive for S. haematobium were treated with a single oral dose of praziquantel $(40 \mathrm{mg} / \mathrm{kg})$. All information obtained from each study participant was kept confidential.

\section{Consent for publication}

Not applicable.

\section{Competing interests}

The authors declare that they have no competing interests.

\section{Author details}

${ }^{1}$ Unité de Formation et de Recherche Sciences de la Nature, Université Nangui Abrogoua, 02 B.P. 801, Abidjan 02, Côte d'Ivoire. ${ }^{2}$ Centre Suisse de Recherches Scientifiques en Côte d'Ivoire, 01 B.P. 1303, Abidjan 01, Côte d'Ivoire. ${ }^{3}$ Unité de Formation et de Recherche Biosciences, Université Félix Houphouët-Boigny, 22 B.P. 582, Abidjan 22, Côte d'Ivoire. ${ }^{4}$ Laboratoire de Parasitologie - Mycologie, Institut National de Recherches en Santé Publique, B.P, 695 Nouakchott, Mauritania. ${ }^{5}$ Centre d'Entomologie Médicale et Vétérinaire (CEMV), Université Alassane Ouattara, Bouaké, Côte d'Ivoire. Eniversité Péléforo Gon Coulibaly, B.P, 1328, Korhogo, Côte d'Ivoire. ${ }^{7}$ Swiss Tropical and Public Health Institute, P.O. Box, CH-4002 Basel, Switzerland. ${ }^{8}$ University of Basel, P.O. Box, CH-4003 Basel, Switzerland. ${ }^{9}$ Centre for Neglected Tropical Diseases, Liverpool School of Tropical Medicine, Pembroke Place, Liverpool L3 5QA, UK.

Received: 24 March 2017 Accepted: 11 July 2017

Published online: 26 July 2017

\section{References}

1. Jordan P. From Katayama to Dakhla oasis: the beginning of epidemiology and control of bilharzias. Acta Trop. 2000;77:9-40.

2. Hotez JP, Alvarado M, Basáñez MG, Bolliger I, Bourne R, Boussinesq M, et al. The Global Burden of Disease study 2010: interpretation and implications for the neglected tropical diseases. PLoS Negl Trop Dis. 2014;8:e2865.

3. WHO. Schistosomiasis and soil-transmitted helminthiases: number of people treated in 2015. Wkly Epidemiol Rec. 2016:91:585-600.

4. WHO. Fact sheet $N^{0} 115,2015$ Updated May 2015.

5. N'Goran EK, Diabate S, Utzinger J, Selin B. Changes in human schistosomiasis levels after the construction of two large hydroelectric dams in central Côte d'Ivoire. Bull World Health Organ. 1997;75:541-5.

6. Rollinson D, Webster JP, Webster B. Genetic diversity of schistosomes and snails: implications for control. Parasitology. 2009;136:1801-11.

7. Adenowo AF, Oyinloye BE, Ogunyinka BI, Kappo AP. Impact of human schistosomiasis in sub-Saharan Africa. Braz J Infect Dis. 2015;19:196-205.

8. McCreesh N, Nikulin G, Booth M. Predicting the effects of climate change on Schistosoma mansoni transmission in eastern Africa. Parasit Vectors. 2015;8:4.

9. Ouédraogo M, Servat E, Paturel JE. Caractérisation d'une modification éventuelle de la relation pluie-débit autour des années 1970 en Afrique de l'ouest et centrale non sahélienne. Water Ressources Variability in Africa during the $X X^{\text {th }}$ Century (Proceedings of the Abidjan 98 Conference held à Abidjan, Côte d'Ivoire), IAHS Pub/ no 252, 1998.

10. Southgate VR. Schistosomiasis in the Senegal River basin: before and after the construction of the dams at Diama, Senegal and Manantali, Mali and future prospects. J Helminthol. 1997;71:125-32.

11. Sow S, de Vlas SJ, Engels D, Gryseels B. Water-related disease patterns before and after the construction of the Diama dam in northern Senegal. Ann Trop Med Parasitol. 2002;96:575-86.

12. Utzinger J, Raso G, Brooker S, de Savigny D, Tanner M, Ørnbjerg N, et al. Schistosomiasis and neglected tropical diseases: towards integrated and sustainable control and a word of caution. Parasitology. 2009;136:1859-74.

13. Secor WE. Water-based interventions for schistosomiasis control. Pathog Glob Health. 2014;108:246-54.

14. Utzinger J, Zhou XN, Chen MG, Bergquist R. Conquering schistosomiasis in China: the long march. Acta Trop. 2005;96:69-96.

15. Muhumuza S, Kitimbo G, Oryema-Lalobo M, Nuwaha F. Association between socio economic status and schistosomiasis infection in Jinja district. Uganda, Trop Med Int Health. 2009;14:612-9.

16. Ouldabdallahi M, Ouldbezeid M, Diop C, Dem E, Konate K. Epidemiology of human schistosomiasis in Mauritania. The right bank of the Senegal River as model. Bull Soc Path Exot. 2010;103:74-8. 
17. Salem Ould Ahmed CB, Alassane MT. Study of prevalence and parasite load of urinary schistosomiasis in schoolchildren in the Wilaya of Gorgol (Mauritania). Med Trop. 2011;71:261-3.

18. Diop MD, Jobin WR, Nicolas AG, Fereydoun A, Minor BS, Aubel J, et al. Senegal River basin health master plan study, Prepared for the USAID Mission to Senegal U. S. Agency for International Development under WASH Task No. 5 12; 1994. p. 163. http://pdf.usaid.gov/pdf_docs/ PNABW752.pdf. Accessed 10 Mar 2017.

19. Ndiaye EHM. Le fleuve Sénégal et les barrages de l'OMVS: quels enseignements pour la mise en œuvre du NEPAD? VertigO - la revue électronique en sciences de l'environnement. 2003:4:3.

20. Rollinson D, Knopp S, Levitz S, Stothard RJ, Tchuem Tchuenté LA, Garba A, et al. Time to set the agenda for schistosomiasis elimination. Acta Trop. 2013;128:423-40.

21. Plouvier S, Leroy JC, Colette J. A propos d'une technique simple de filtration des urines dans le diagnostic de la bilharziose urinaire en enquête de masse. Med Trop. 1975;35:229-30.

22. WHO. Prevention and control of schistosomiasis and soil-transmitted helminthiasis: report of a WHO expert committee. WHO Tech Rep Ser. 2002;912:1-57.

23. Yapi YG, Toure M, Boka OM, Tia E, Boby OAM, Kadjo KA. Dynamique des populations de Biomphalaria pfeifferi et de Bulinus globosus en zone d'endémie schistosomienne en Côte d'Ivoire. Eur Sci J. 2014;10:339-69.

24. Sellin B, Rey JL, Simonkovich E, Sellin E, Mouchet F. Essai de lutte par chimiothérapie contre Schistosoma haematobium en zone irriguée sahélienne au Niger. Med Trop. 1986;46:21-30.

25. Frandsen $F$, Christensen NO. An introductory guide to the identification of cercariae from African freshwater snails with special reference to cercaria of trematode species of medical and veterinary importance. Acta Trop. 1984:41:181-202.

26. Brown DS. Freshwater snails of Africa and their medical importance. London: Taylor and Francis Ltd; 1994. p. 609.

27. Dalton PR. A socioecological approach to the control of Schistosoma mansoni in St Lucia. Bull World Health Organ. 1976;54:587-95.

28. Sow S, de Vlas SJ, Stelma F, Vereecken K, Gryseels B, Polman K. The contribution of water contact behavior to the high Schistosoma mansoni infection rates observed in the Senegal River basin. BMC Inf Dis. 2011;11:198.

29. Corp S. Stata statistical software: release 14. College Station, TX: Stata Corp LP; 2015.

30. Jobin RW, Aponte NH, Michelson HE. Schistosomiasis in the Gorgol valley of Mauritania. Am J Trop Med Hyg. 1976;25:587-94.

31. Ouedraogo H, Drabo F, Zongo D, Bagayan M, Bamba I, Pima T, et al. Schistosomiasis in school-age children in Burkina Faso after a decade of preventive chemotherapy. Bull World Health Org. 2016;94:37-45.

32. Niangaly H, Djimde AA, Traore B, Sangare CPO, Guindo D, Konate D, et al. Seasonal variability of intestinal helminths and Schistosoma haematobium in a rural area of the Sahel in Mali. Med Santé Trop. 2012;22:430-4.

33. Ahmed MA, Abbas H, Mansour AF, Gasim IG, Adam I. Schistosoma haematobium infections among schoolchildren in central Sudan one year after treatment with praziquantel. Parasit Vectors. 2012;5:108.

34. Clements ACA, Firth S, Dembele R, Garba A, Toure S, Sacko M, et al. Use of Bayesian geostatistical prediction to estimate local variations in Schistosoma haematobium infection in western Africa. Bull World Health Organ. 2009;87:921-9.

35. Senghor B, Diallo A, Sylla SN, Doucouré S, Ndiath MO, Gaayeb L, et al. Prevalence and intensity of urinary schistosomiasis among school children in the district of Niakhar, region of Fatick, Senegal. Parasit Vectors. 2014;7:5.

36. Ibikounlé $M$, Ogouyèmi-Hounto $A$, Sissinto Savi de Tové $Y$, Dansou $A$, Courtin D, Kindé-Gazard D, et al. Epidemiology of urinary schistosomiasis among schoolchildren in Péhunco area, northern Benin. Malacological survey. Bull Soc Pathol Exot. 2014;107:177-84.

37. Shashie G, Agersew A, Sisay G, Zeleke M, Berhanu E. Prevalence of urinary schistosomiasis and associated risk factors among Abobo primary school children in Gambella regional state, southwestern Ethiopia: a cross sectional study. Parasit Vectors. 2015;8:215.

38. Kazibwe F, Makanga B, Rubaire AC, Ouma J, Kariuki C, Kabatereine NB, et al. Transmission studies of intestinal schistosomiasis in Lake Albert, Uganda and experimental compatibility of local Biomphalaria spp. Parasitol Int. 2010;59:49-533.

39. Hassan AO, Amoo AOJ, Akinwale OP, Deji-Agboola AM, Adeleke MA, Gyang $P V$, et al. Human water contact activities and urinary schistosomiasis around Erinle and Eko-Ende dams. Global Adv Res J Med Med Sci. 2012;1:77-84.
40. Dalton PR, Pole D. Water-contact patterns in relation to Schistosoma haematobium infection. Bull World Health Org. 1978:56:417-26.

41. Mazigo HD, Nuwaha F, Kinung'hi SM, Morona D, de Moira AP, Wilson S, et al. Epidemiology and control of human schistosomiasis in Tanzania. Parasit Vectors. 2012;5:274.

42. WHO. Lutte contre la schistosomiase et les parasitoses intestinales. Rapport de la consultation informelle de l'O.M.S. sur la lutte contre la schistosomiase. Geneva: World Health Organization; 1998.

43. Kristensen $\mathrm{KT}$, Madsen $\mathrm{H}$, Stensgaard AS. The role of snails in schistosomiasis research - from taxonomy to forecasting disease outbreaks. In: Olsen A, Ørnbjerg N, Winkel K, editors. A succes story in Danish development aid DBL (1964-2012). Institute for Health Research and Development: University of Copenhagen; 2013. p. 61-5.

44. WHO. Snail control in the prevention of bilharziasis: report of a WHO expert committee. WHO Tech Rep Ser. 1965;50:1-255.

45. Senghor B, Diaw OT, Doucoure S, Seye M, Talla I, Diallo A, et al. Study of the snail intermediate hosts of urogenital schistosomiasis in Niakhar, region of Fatick, west Central Senegal. Parasit Vectors. 2015;8:410.

46. Southgate VR, Tchuem Tchuenté LA, Sène M, De Clercq D, Théron A, Jourdane J, et al. Studies on the biology of schistosomiasis with emphasis on the Senegal River basin. Mem Inst Oswaldo Cruz. 2001;96(Suppl.):75-8.

47. Sène M, Southgate VR, Vercruysse J. Bulinus truncatus, hôte intermediaire de Schistosoma haematobium dans le bassin du fleuve Sénégal. Bull Soc Pathol Exot. 2004;97:29-32.

48. Kristensen TK, Stensgaard AS. Bulinus senegalensis. The IUCN Red List of Threatened Species 2010: e.T165398A6015514. 2010. (http://dx.doi.org/10. 2305/IUCN.UK.2010-3.RLTS.T165398A6015514 Accessed 4 Oct 2016).

49. Ekwunife CA. Socio-economic and water contact studies in Schistosoma haematobium infested area of Anambra State, Nigeria. Anim Res Int. 2004;1: 200-2.

50. Dabo A, Badawi HM, Bary B, Doumbo OK. Urinary schistosomiasis among preschool-aged children in Sahelian rural communities in Mali. Parasit Vectors. 2011:4:21

51. Omonijo A, Asaolu S, Ofoezie I. Schistosomiasis transmission and water contact pattern in river Ureje in Ado-ekiti local government area, Ekiti State. Res J Parasitol. 2013;8:26-36.

52. Etard JF, Borel E. Water contact and urinary schistosomiais in a Mauritanian village. Rev Epidém Santé Publ. 1992;40:268-75.

53. Traoré I, Karthe D, Sie A, Coulibaly V, Kappas M. Influence of air temperature on children water contacts with respect to schistosomiasis transmission risk in the Sourou Valley, Burkina Faso. Stoch Environ Res Risk Assess. 2016:30:2097-107.

54. Scott JT, Diakhaté M, Vereecken K, Fall A, Diop M, Ly A, et al. Human water contacts patterns in Schistosoma mansoni epidemic foci in northern Senegal change according to age, sex and place of residence, but are not related to intensity of infection. Trop Med Int Health. 2003:8:100-8.

55. Fulford AJ, Ouma JH, Kariuki HC, Thiongo FW, Klumpp R, Kloos H, et al. Water contact observations in Kenyan communities endemic for schistosomiasis: methodology and patterns of behaviour. Parasitology. 1996;113:223-41.

56. Gazzinelli A, Bethony J, Fraga LA, LoVerde PT, Corréa-Oliveira R, Kloos H. Exposure to Schistosoma mansoni infection in a rural area of Brazil. I: water contact. Trop Med Int Health. 2001;6:126-35.

\section{Submit your next manuscript to BioMed Central and we will help you at every step:}

- We accept pre-submission inquiries

- Our selector tool helps you to find the most relevant journal

- We provide round the clock customer support

- Convenient online submission

- Thorough peer review

- Inclusion in PubMed and all major indexing services

- Maximum visibility for your research

Submit your manuscript at www.biomedcentral.com/submit 